\title{
Effect of Substrate, Feeding Mode and Number of Stages on the Performance of Hybrid Constructed Wetland Systems
}

\author{
José Alberto Herrera-Melián *, Alejandro Borreguero-Fabelo, Javier Araña, \\ Néstor Peñate-Castellano and José Alejandro Ortega-Méndez
}

\author{
Institute of Environmental Studies and Natural Resources (i-UNAT), University of Las Palmas de Gran Canaria, \\ 35017 Las Palmas, Spain; a.borreguero@hotmail.com (A.B.-F.); javier.arana@ulpgc.es (J.A.); \\ nestorp1990@gmail.com (N.P.-C.); alejandro.ortega@ulpgc.es (J.A.O.-M.) \\ * Correspondence: josealberto.herrera@ulpgc.es
}

Received: 30 October 2017; Accepted: 2 January 2018; Published: 5 January 2018

\begin{abstract}
A hybrid constructed wetland mesocosm has been used for the treatment of raw urban wastewater. The first stage was a mulch-based, subsurface, horizontal flow constructed wetland (HF). The HF achieved good removals of COD $\left(61 \% ; 54 \mathrm{~g} / \mathrm{m}^{2} \cdot\right.$ day) and Total Suspended Solids $\left(84 \% ; 29 \mathrm{~g} / \mathrm{m}^{2}\right.$.day). The second stage was composed of vertical flow constructed wetlands (VF) that were employed to study the effect of substrate (gravel vs. mulch), feeding mode (continuous vs. intermittent) and the number of stages (1 vs. 2) on performance. High hydraulic and organic surface loadings $\left(513-583 \mathrm{~L} / \mathrm{m}^{2}\right.$. day and $103-118 \mathrm{~g} / \mathrm{m}^{2}$. day of COD) were applied to the reactors. The mulch was more efficient than gravel for all the parameters analyzed. The continuous feeding allowed a 3 to 6-fold reduction of the surface area required.
\end{abstract}

Keywords: forest waste; palm mulch; constructed wetlands; vertical flow

\section{Introduction}

The supply of water has always been a matter of great concern for the inhabitants of the Canary Islands (Spain), particularly in the second half of the 20th century when a remarkable increment of the population coincided with a strong decreasing trend in precipitation [1]. Additionally, the steep orography with altitudes up to $3700 \mathrm{~m}$ and the presence of many disseminated small communities, reinforce the idea of the adequacy of non-conventional or decentralized systems for wastewater treatment and reuse on the islands [2].

In the last decades constructed wetlands (CWs) have gained increasing popularity for wastewater treatment in small communities. CWs are easily designed and constructed, and maintenance is simple and economic as it does not require highly skilled personnel or expensive machinery. The cost of domestic wastewater treatment with CWs varies with land price but it can be about 2-3 times lower than that of conventional treatment processes [3]. Besides being highly efficient and robust, CWs also add aesthetic, ecological and cultural values [4]. Life cycle comparisons of CWs vs. activated sludge technology have shown that the former emit less greenhouse gases and cause less environmental impact [5]. However, two important disadvantages of CWs can limit their implantation: the large surface area required and in the case of subsurface flow CWs, the clogging of the substrate [6].

Vertical flow CWs (VFs) require less surface area than horizontal flow CWs (HFs) because of the higher substrate aeration efficiency of the former [7]. Consequently, the applicability of VFs or hybrid systems including VFs is expected to be higher in places where the land is costly or scarce, or if the reclaimed water is intended to be used in irrigation, since water loss by evapotranspiration and the consequent salinity increment will be lower. This is the situation in many regions with 
Mediterranean-like weather like the Canary Islands [8-10]. An example of a remarkably efficient VF, capable of treating raw domestic wastewater without primary settling is the so-called "French system". The classical design consists of two stages of unsaturated VFs in series with feeding/rest periods of 1 or 2 weeks [11]. Besides, the environmental impact of VFs is smaller than that of HFs because the former emit fewer greenhouse gases during wastewater treatment and have lower construction requirements. The construction impacts could be significantly reduced by using local materials so that transportation of the wetland substrate would be minimized [5,12]. Nevertheless, VFs can become clogged more easily than HFs because of the use of substrates with smaller particle size [6,13]. Consequently, it has been suggested that in hybrid CWs, the HF should be the first stage and VFs the second one [8].

Gravel is the conventional substrate of CWs. This mineral material supports the attached-growth biomass and plants but has a low capacity for sorption and precipitation [14]. Hence, other materials such as rice husk [15] and peat/crushed pine bark [16] have been successfully tested. Organic substrates have also been used as electron donors for sulfate reducers in passive remediation systems for the treatment of acid mine drainage [17]. Another remarkable application of organic substrates is the treatment of low $\mathrm{C} / \mathrm{N}$ wastewater as extra carbon is needed to enhance denitrification efficiency [18]. Agricultural and forest organic wastes can be good substrates of CWs. This practice can have several environmental and economic advantages compared with mineral substrates (gravel and sand) by: (i) providing a viable solution to reduce waste materials in a cheap and eco-friendly way, (ii) adding economic value to the waste, (iii) reducing the impact of CWs construction as a renewable, locally abundant material would be used. Additionally, these materials offer an interesting advantage, which is their capacity to work as low cost bio-sorbents [19,20]. Ribé et al. [21] observed that pine bark was able to efficiently remove heavy metals from landfill leachates. Gao et al. [22] studied a $600 \mathrm{~m}^{2} \mathrm{VF}$ and with a substrate that contained about $37 \%$ organic matter including wood turf, organic compost, activated sludge and pine bark. The authors claimed that the substrate had good porosity to prevent clogging which is a fatal threat for the subsurface-flow CW.

The Canarian palm tree (Phoenix canariensis) is native to the Canary Islands and has been introduced throughout the world as an ornamental plant. The plant shows good resistance to hot and dry environments and adapts well to drought [23]. Its stipe can reach $20 \mathrm{~m}$ in height and 30-40 cm in diameter. The pinnate leaves are 5-6 $\mathrm{m}$ in length. Thus, taking into account that palm mulch is an abundant, cheap, renewable material, the main goals of this research were:

- $\quad$ To check the performance of a mulch-based HF as the first stage of a hybrid CW after 3 years in operation.

- $\quad$ Regarding the second stage VF:

- To compare gravel with mulch as substrates for VFs.

○ To compare the continuous feeding mode with intermittent feeding mode.

$0 \quad$ To determine the number of VFs in series to meet the European legal limits for effluent discharge regarding TSS (35 mg/L) and organic matter (BOD: $25 \mathrm{mg} / \mathrm{L}, \mathrm{COD}$ : $125 \mathrm{mg} / \mathrm{L})$ [24].

\section{Materials and Methods}

The influent, raw wastewater from the Campus of the University of Las Palmas de Gran Canaria (Canary Islands, Spain) was collected from a $17-\mathrm{m}^{3}$ tank with a timer-controlled, triturating pump located at the bottom of the tank. The pump-timer was programmed to function every $2 \mathrm{~h}$ (12 times a day) for $1 \mathrm{~min}$. Daily inflows to the primary CWs were determined by measuring the influent volume with graduated recipients.

\subsection{Constructed Wetland (CW) Mesocosms}

The first stage HF (Figure 1) was built with three 265-L polypropylene recipients (length: $125 \mathrm{~cm}$, height: $57 \mathrm{~cm}$, width: $56 \mathrm{~cm}$, surface area: $0.7 \mathrm{~m}^{2}$, Prograrden, Italy). The three recipients contained 
only palm mulch as substrate and were planted with common reed and papyrus. The HF has been in operation since September 2011 [25]. The surface area of this CW was $2.1 \mathrm{~m}^{2}$.

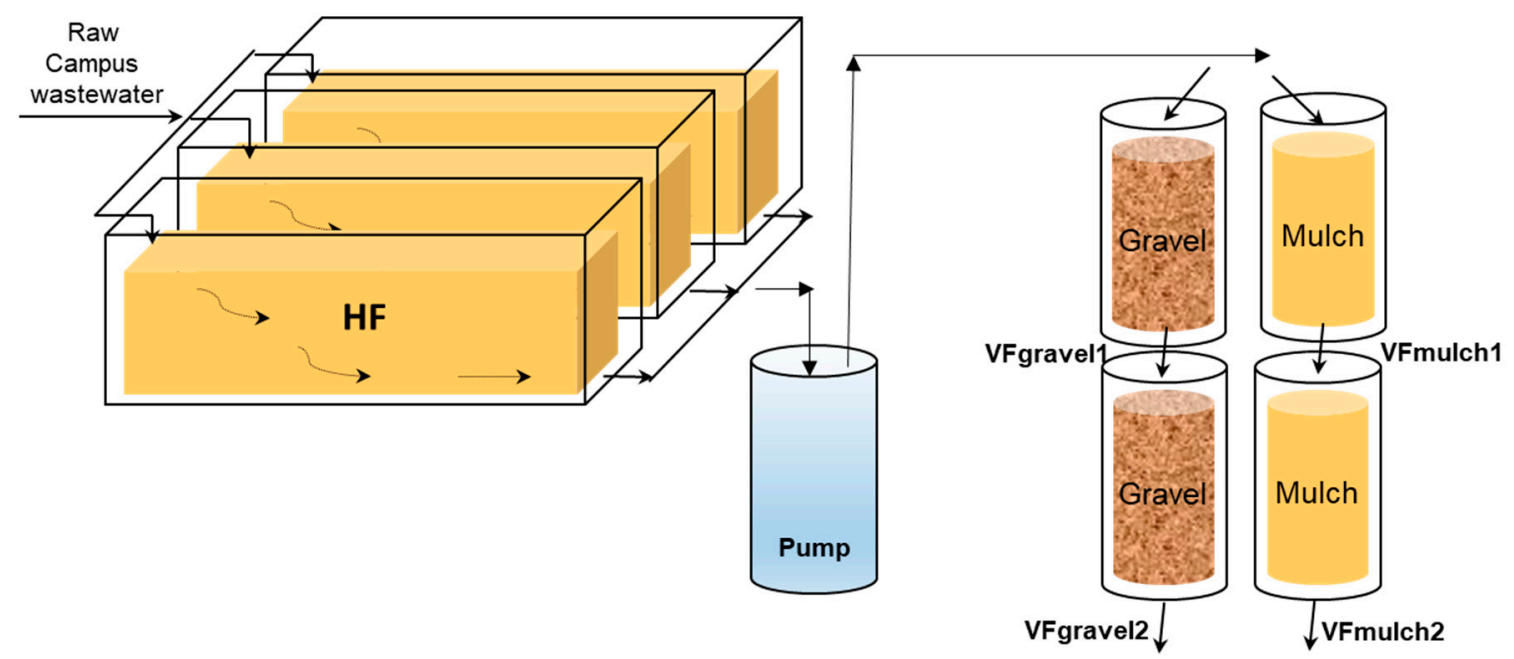

Figure 1. Layout of the hybrid CW: the mulch-based, horizontal flow (HF) and VFs with gravel (VFgravel) and mulch (VFmulch).

The HF1 effluent was collected in a recipient from which it was pumped into two lab-scale VFs containing only gravel (VFgravel) and only palm mulch (VFmulch). The gravel was basaltic with $49 \%$ porosity and average diameter of $6.5 \mathrm{~mm}$. Both reactors were composed of two plastic, cylindrical recipients in series, each with a height of $80 \mathrm{~cm}$ and a surface area of $0.1 \mathrm{~m}^{2}$. The mulch was a heterogeneous material obtained from the trituration of dry branches of the Canarian palm tree (Phoenix canariensis). The mulch had a porosity of $54 \%$ and a hygroscopicity of $10 \%$. These VFs were designed to determine the effect of the influent feeding mode (continuous vs. pulse) and to determine the number of VFs in series to meet the European legal limits for the discharge of treated wastewater into the environment. These reactors were in operation between July and December 2013 and between February and July 2014.

All the reactors were placed outdoors at the Campus of Tafira, Gran Canaria, Canary Islands, Spain (latitude: $28^{\circ} 4^{\prime}$ North, longitude: $15^{\circ} 27^{\prime}$ West). The height above the sea level is $305.5 \mathrm{~m}$. The climate is spring-like the year round because of the influence of the trade winds. The average summer temperatures are mild $\left(22^{\circ} \mathrm{C}\right)$ and not very different from those of the winter $\left(13^{\circ} \mathrm{C}\right.$ minimum). Rainfall is extremely scarce with annual averages ranging between 150 and $200 \mathrm{~mm}$ [26]. Evapo-transpiration is about 65\% of the average annual rainfall [10].

\subsection{Water Analysis}

Water quality parameters were measured in unfiltered, homogenized samples as described by standard methods [27]. Hence, total $\mathrm{BOD}_{5}$ and $\mathrm{COD}$ were measured. $\mathrm{BOD}_{5}$ (henceforth $\mathrm{BOD}$ ) can include nitrification as no inhibitor was added. $\mathrm{NH}_{4}{ }^{+}$, and $\mathrm{Na}^{+}$ions were determined with selective electrodes from Crison (Barcelona, Spain). $\mathrm{PO}_{4}{ }^{3-}$ ions were dissolved, molybdate-reactive phosphates. Permanent hardness $\left(\mathrm{Ca}^{2+}+\mathrm{Mg}^{2+}\right)$ was determined by the EDTA titrimetric method. The concentration of fecal coliforms (FC) was determined by the membrane filter method and incubation at $44{ }^{\circ} \mathrm{C}$ for $24 \mathrm{~h}$ with the Chapmann-TTC agar medium.

\subsection{Statistics}

The statistics applied in this study have been described in detail in [25]. In brief, average values of concentrations, surface loadings and removals were compared by means of the Anova if the data were homocedastic (Bartlett test) and normally distributed (Shapiro-Wilk test). If these conditions 
were not met the Kruskal-Wallis non parametric test was used. In all cases a significance level of $95 \%$ ( $p$-value $>0.05)$ was used. Correlation between variables was tested with Pearson and Spearman tests with the same significance level.

\section{Results and Discussion}

\subsection{Characteristics of the Influent}

The influent was raw wastewater from the Campus and included those from cafeterias, laboratories and toilets. The influent was collected from a $17-\mathrm{m}^{3}$ tank with a timer-controlled triturating pump placed at the bottom of the tank. The pump timer was programmed to function every day for 1 min every $2 \mathrm{~h}$ during all the experimental period. Table 1 shows the features of the influent during the experimental time. According to the concentrations of organic matter, solids and ammonia the influent can be considered a medium to strong urban wastewater. Additionally, the high variability shown by the standard deviation values can be influenced by the daily operations within the Campus.

Table 1. Characteristics of the wastewater used in this work. Average concentrations \pm standard deviation and number of data $(n)$ between January 2013 and July 2014.

\begin{tabular}{ccc}
\hline Parameter & Value & Units \\
\hline $\mathrm{BOD}_{5}$ & $444 \pm 131, n: 59$ & $\mathrm{mg} / \mathrm{L}$ of $\mathrm{O}_{2}$ \\
$\mathrm{COD}$ & $552 \pm 162, n: 71$ & $\mathrm{mg} / \mathrm{L}$ of $\mathrm{O}_{2}$ \\
TSS & $252 \pm 133, n: 64$ & $\mathrm{mg} / \mathrm{L}$ \\
Turbidity & $209 \pm 97, n: 82$ & $\mathrm{NTU}$ \\
$\mathrm{NH}_{4}{ }^{+}$ & $68 \pm 21, n: 60$ & $\mathrm{mg} / \mathrm{L}$ \\
$\mathrm{PO}_{4}^{3-}$ & $34 \pm 8, n: 18$ & $\mathrm{mg} / \mathrm{L}$ \\
$\mathrm{FC}^{+}$ & $1.91( \pm 1.48) \times 10^{7}, n: 15$ & $\mathrm{CFU} / 100 \mathrm{~mL}$ \\
$\mathrm{Na}^{+}$ & $155 \pm 40, n: 10$ & $\mathrm{mg} / \mathrm{L}$ \\
$\mathrm{pH}$ & $6.93 \pm 0.27, n: 29$ & $\mathrm{pH} \mathrm{units}$ \\
Permanent hardness $\left(\mathrm{Ca}^{2+}+\mathrm{Mg}^{2+}\right)$ & $1665 \pm 590, n: 29$ & $\mathrm{mS} / \mathrm{cm}$ \\
\hline
\end{tabular}

\subsection{Performance of the First Stage HF}

A mulch-based HF can provide remarkable results in the treatment of urban wastewaters with no evident clogging symptoms even at high surface loading rates (LRs) [25]. However, to our knowledge no research has been devoted to determine performance of mulch-based CWs in the long term. HF has been in operation with different configurations since September 2011. Hence, one of the goals of this study was to determine HF performance and clogging after 3 years. The results considered in this study comprise those obtained between January 2013 and July 2014. Table 2 shows the average LRs ( \pm standard deviation) and removals obtained by the HF.

Table 2. Average LRs and removals ( \pm standard deviation) of the HF.

\begin{tabular}{ccc}
\hline Parameter & LR & Removal, $\%$ \\
\hline $\mathrm{HLR}, \mathrm{L} / \mathrm{m}^{2} \cdot$ day & $146 \pm 52$ & - \\
$\mathrm{BOD}, \mathrm{g} / \mathrm{m}^{2}$.day & $64 \pm 23$ & $68 \pm 19$ \\
$\mathrm{COD}, \mathrm{g} / \mathrm{m}^{2} \cdot$ day & $88 \pm 38$ & $61 \pm 14$ \\
$\mathrm{TSS}, \mathrm{g} / \mathrm{m}^{2} \cdot$ day & $35 \pm 39$ & $84 \pm 8$ \\
Turbidity, $\mathrm{NTUxL} / \mathrm{m}^{2} \cdot$ day & $65 \pm 22$ & $77 \pm 12$ \\
$\mathrm{NH}_{4}{ }^{+}, \mathrm{g} / \mathrm{m}^{2} \cdot$ day & $9 \pm 3$ & $-21 \pm 25$ \\
$\mathrm{PO}_{4}{ }^{3-}, \mathrm{g} / \mathrm{m}^{2} \cdot$ day & $4 \pm 1$ & $-11 \pm 19$ \\
Fecal coliforms, $\mathrm{CFU} / \mathrm{m}^{2} \cdot$ day & $2.6( \pm 2.3) \times 10^{10}$ & $75 \pm 24$ \\
\hline
\end{tabular}


As can be observed on Table 2, removals of TSS (84\%) and turbidity (78\%) were quite good. TSS are the main cause of clogging in CWs [6]. Thus, it is important to achieve high TSS removal if the following treatment stage in the hybrid CW is a VF.

COD removal $\left(61 \%, 54 \mathrm{~g} / \mathrm{m}^{2}\right.$.day) was better than those achieved by conventional HFs and VFs, that range between 10 [28] and $20 \mathrm{~g} / \mathrm{m}^{2}$.day [29]. Greater performances have been obtained with non-conventional CWs such as intermittently aerated VFs (57 g/ $\mathrm{m}^{2}$.day) [30] and tidal flow CWs $\left(62 \mathrm{~g} / \mathrm{m}^{2}\right.$.day) [31] but these reactors require more energy input and/or device implementation.

Ammonia can be removed from CW water by different mechanisms that include volatilization, nitrification or plant uptake [14]. In the present study the average influent concentration of ammonia was $68 \mathrm{mg} / \mathrm{L}$. The ion concentration was increased by $21 \%$. Such increment can be caused by ammonification, i.e., the release of ammonia from organic $\mathrm{N}$, in addition to the lack of enough dissolved oxygen for nitrification. Ammonification process is faster than nitrification [32]. Ammonification occurs in aerobic, facultative and anaerobic conditions but reaction becomes slower with reduced concentrations of dissolved oxygen [14].

No phosphate removal was achieved by HF $(-11 \%)$. In fact, the increment observed could be caused by desorption from the mulch or by mineralization of organic phosphorus. In this case, phosphate desorption from the substrate is not likely as it has been in operation for 3 years. Figure 2 illustrates the concentrations of TSS, COD, turbidity and fecal coliforms in the effluent of HF vs. LR.

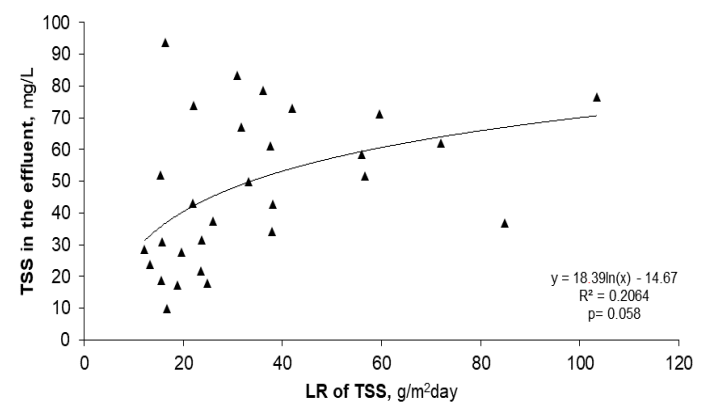

(a)

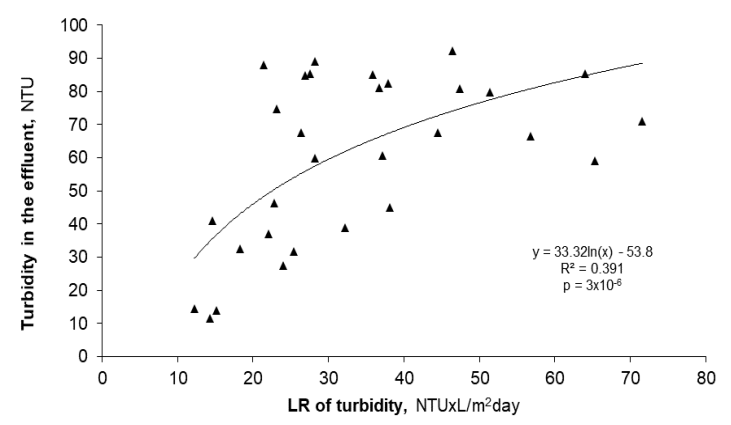

(c)

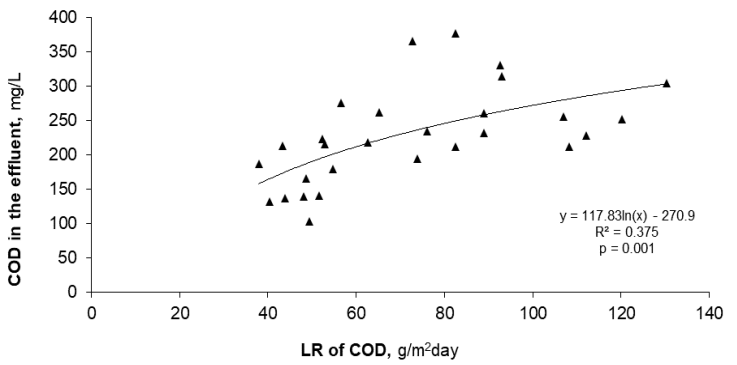

(b)

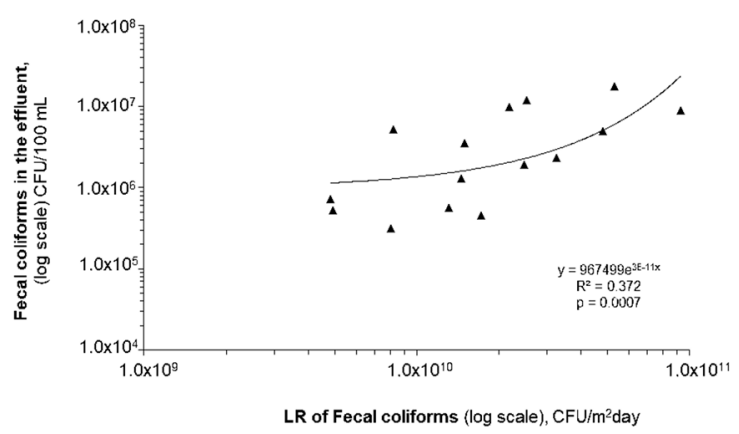

(d)

Figure 2. Concentration of (a) TSS, (b) COD, (c) turbidity and (d) fecal coliforms in the effluent of HF vs. LR. Values of $R^{2}$ and Spearman correlation coefficient are provided.

Although $R^{2}$ values were not particularly high, the best correlations between LRs and effluent concentrations were logarithmic for TSS, COD and turbidity (Figure 2). This results shows that the effluent concentrations were increased with LRs until an upper limit. At higher LR values, the effluent concentrations were independent of LRs. In the case of fecal coliforms, the best correlation was exponential, indicating the low robustness of HF regarding the removal of this parameter. In fact, the average removal of coliforms was relatively poor $(75 \%$, Table 2$)$. 
According to the results obtained in this study (Figure 2), the design guidelines for a mulch-based HF used as a first stage of a hybrid CW, would be $15-30 \mathrm{~g} / \mathrm{m}^{2}$. day for TSS and $40-60 \mathrm{~g} / \mathrm{m}^{2}$. day for COD. These guidelines can be considered conservative as correspond to the lowest LRs used in these experiments. During this 3-year study, mulch (about 10\%) has been added to the reactors in several occasions because of degradation, however no clogging symptoms have been observed. This can be explained by the good porosity of the mulch, the presence of the plants, and the rest periods imposed by the low activity in the Campus during the students' holydays (Christmas, Easter and summer). During these rest periods, the fragmentation and degradation of the deposited organic solids should be accomplished. Paing et al. claimed that rest periods seem to be indispensable to achieve their remarkable performance and to delaying clogging in French VFs [11].

\subsection{Second Hybrid CW Stage: the VFs}

Mulch was compared with gravel as substrates of secondary VFs by determining the effect of the influent feeding mode (pulse versus continuous) and the effect of the number of VFs (1 or 2) on performance. The European legal limits for the discharge of treated wastewater into the environment regarding organic matter (COD: $125 \mathrm{mg} / \mathrm{L}, \mathrm{BOD}: 25 \mathrm{mg} / \mathrm{L})$ and TSS $(35 \mathrm{mg} / \mathrm{L})$ were taken as reference.

\subsubsection{Effect of the Number of VFs}

These experiments were performed between July and November 2013. During this period the reactors were fed continuously with a peristaltic pump with HF1 effluent (Figure 1). Samples were taken in the influent, effluent of the first VFs with gravel (VFgravel1) and mulch (VFmulch1) and in the effluents of the second VFs with gravel (VFgravel2) and mulch (VFmulch2). The HLR of the VFgravel $(558 \pm 213) \mathrm{L} / \mathrm{m}^{2}$. day was similar to that of the VFmulch $(556 \pm 216) \mathrm{L} / \mathrm{m}^{2} \cdot$ day. Note that these HLR are remarkably higher than those used in French VFs (median HLR: $60 \mathrm{~L} / \mathrm{m}^{2}$.day) and German VFs (median HLR: $300 \mathrm{~L} / \mathrm{m}^{2}$.day) [6]. Moreover, in this study all the LR of the VFgravel were similar to those of the VFmulch $(p>0.2)$. Table 3 summarizes the results obtained.

Table 3. Average concentrations ( \pm standard deviation) of COD, BOD, TSS, turbidity and ammonia in the influent and the effluents of the first VFs (VFgravel1 and VFmulch1) and second VFs (VFgravel2 and VFmulch2). The number of data of each sample is 12.

\begin{tabular}{cccccc}
\hline Parameter & Influent & VFgravel1 & VFgravel2 & VFmulch1 & VFmulch2 \\
\hline COD, mg/L & $214( \pm 48)$ & $153( \pm 46)$ & $113( \pm 28)$ & $128( \pm 30)$ & $99( \pm 32)$ \\
BOD, mg/L & $170( \pm 53)$ & $80( \pm 22)$ & $33( \pm 8)$ & $59( \pm 25)$ & $17( \pm 15)$ \\
TSS, mg/L & $34( \pm 22)$ & $9( \pm 3)$ & - & $4( \pm 1)$ & - \\
Turbidity, NTU & $23( \pm 8)$ & $13( \pm 1)$ & $4.5( \pm 2.7)$ & $3.1( \pm 1.2)$ & $1.3( \pm 0.5)$ \\
$\mathrm{NH}_{4}{ }^{+}, \mathrm{mg} / \mathrm{L}$ & $76( \pm 19)$ & $40( \pm 11)$ & $20( \pm 6)$ & $35( \pm 20)$ & $13( \pm 11)$ \\
\hline
\end{tabular}

The LR of COD for VFgravel $\left(103 \pm 45 \mathrm{~g} / \mathrm{m}^{2}\right.$.day) and VFmulch $\left(118 \pm 45 \mathrm{~g} / \mathrm{m}^{2}\right.$.day) were statistically similar. However, the COD concentration of VFgravel1 $(153 \mathrm{mg} / \mathrm{L})$ is relatively far from the reference given by the European legislation $(125 \mathrm{mg} / \mathrm{L})$ while that of VFmuclh1 was closer $(128 \mathrm{mg} / \mathrm{L})$. Nonetheless, there is no significant difference regarding COD effluent concentrations and removals between VFgravel1 and VFmulch1. The effluents of both the second VFs met the COD legal limit, with the VFmulch providing a slightly lower value (VFgravel2: $113 \mathrm{mg} / \mathrm{L}$, VFmulch2: $99 \mathrm{mg} / \mathrm{L}$, Table 3). The presence of the second VFs significantly improved COD removals in both reactors.

The LR of BOD (VFgravel: $82 \mathrm{~g} / \mathrm{m}^{2}$.day, VFmulch: $104 \mathrm{~g} / \mathrm{m}^{2}$. day) were also statistically similar. The average concentrations of BOD in the effluents of VFgravel1 $(80 \mathrm{mg} / \mathrm{L})$ and VFmulch $1(59 \mathrm{mg} / \mathrm{L}$, Table 3) were also similar ( $p=0.0787)$ and above the reference value of $25 \mathrm{mg} / \mathrm{L}$. Nonetheless, BOD concentrations were significantly reduced to $33 \mathrm{mg} / \mathrm{L}$ in VFgravel2 $(p=0.0005)$ and $17 \mathrm{mg} / \mathrm{L}$ in VFmulch2 $(p=0.00027)$, being that of VFmulch2 significantly lower. These results indicate the positive effect of the presence of the second VFs and the better performance of the mulch. 
Performance regarding turbidity was remarkable because the influent value (23 NTU) was reduced to 13 NTU in VFgravel1 while in VFmulch1 the average turbidity was remarkably lower (3.1 NTU, Table $3, p=1.036 \times 10^{-5}$ ). This might be caused by the notably better filtering and retention capacity of particles and colloidal matter of the mulch in the upper part of the VF. Turbidity in VFmulch2 effluent (1.3 NTU) was also clearly lower than in VFgravel2 $\left(3.1 \mathrm{NTU}, p=5.336 \times 10^{-7}\right)$ and below the limit recommended by World Health Organization and the U.S. Environmental Protection Agency for water intended for irrigation (2 NTU) [33]. The second VFs significantly improved turbidity removals (VFgravel, $p=0.0011$; VFmulch, $p=7.74 \times 10^{-5}$ ).

The average concentration of TSS of the influent $(34 \mathrm{mg} / \mathrm{L})$ was reduced to $9 \mathrm{mg} / \mathrm{L}$ in VFgravel1 and to $4 \mathrm{mg} / \mathrm{L}$ in VFmulch1 (Table 3), with VFmulch1 being significantly more efficient.

The ammonia concentration of the influent $(76 \mathrm{mg} / \mathrm{L})$ was reduced to $40 \mathrm{mg} / \mathrm{L}$ in VFgravel1 and $35 \mathrm{mg} / \mathrm{L}$ in VFmulch1 (Table 3) with no significant differences between both values. However, the concentration of ammonia in VFgravel $2(20 \mathrm{mg} / \mathrm{L})$ was significantly greater than that of VFmulch2 $(13 \mathrm{mg} / \mathrm{L})$. Additionally, ammonia removal was significantly improved with the addition of the second VFs (VFgravel, $p=2.75 \times 10^{-6}$; VFmulch, $p=0.0012$ ). Thus, it is possible to achieve a high enough efficiency to meet the European legal limits with high LR by using two continuously fed, mulch-based $\mathrm{CW}$ in series.

\subsubsection{Effect of Influent Feeding Mode (Pulse vs. Continuous)}

The conventional operation of VFs implies the pulse feeding of the influent into the reactors. This way, flooding-drainage periods are alternated and the substrate aeration and biomass contact with the influent are optimized. Consequently, high performance regarding organic matter, nitrification and bacteria can be obtained [34]. Nonetheless, the continuous feeding of VFs can also provide remarkable results [9]. Consequently, it was decided to determine the effect of the influent feeding mode on the performance of the VFs.

The continuous feeding mode was used from July to December 2013. From February to May 2014 the feeding was made pulse and continuous again from May to July 2014. In this way, the possible "memory effects" and that of temperature would be counteracted. The average HLR in the continuous period, $498( \pm 149) \mathrm{L} / \mathrm{m}^{2}$.day for VFgravel and $576( \pm 193) \mathrm{L} / \mathrm{m}^{2}$.day for VFmulch, were not statistically equal. During the pulse feeding period the HLRs of each reactor, $379( \pm 234)$ $\mathrm{L} / \mathrm{m}^{2}$. day and $313( \pm 124) \mathrm{L} / \mathrm{m}^{2}$. day for the VFgravel and VFmulch, respectively were not significantly different either. The reason for such different HLRs in each period is that the influent volume required to achieve similar HLR to those of the continuous feeding was very high. Hence, the resulting HRT and the corresponding removals were notably low (data not shown). The results from the two continuous periods are considered together. The number of samples was 21 for the continuous period and 17 for the pulse feeding period. Table 4 provides the LR of both reactors and the removals achieved for each feeding mode. Figure 3 shows the concentrations of the influent (effluent of HF1) and those of the effluents of VFmulch2 and VFgravel2 vs. time for the continuous and pulse feeding periods.

In the case of $\mathrm{BOD}$, it is not possible to compare the effect of the feeding mode because the resulting BOD LR for each period were very different (Table 4). Nevertheless, for the continuous feeding period the BOD LR of both reactors are comparable (VFgravel: $76 \pm 48 \mathrm{~g} / \mathrm{m}^{2}$.day, VFmulch: $101 \pm 59 \mathrm{~g} / \mathrm{m}^{2}$.day, $p=0.1739$ ). The same applies for the pulse feeding period (VFgravel: $22 \pm 26 \mathrm{~g} / \mathrm{m}^{2}$.day, VFmulch: $17 \pm 16 \mathrm{~g} / \mathrm{m}^{2}$.day, $\left.p=0.729\right)$. Hence, VFmulch (91\%) was statistically better than VFgravel $(78 \%)$ when the feeding was continuous $(p=0.007)$. This led to significantly lower average BOD effluent concentrations in VFmulch $(11 \mathrm{mg} / \mathrm{L})$ than in VFgravel $(30 \mathrm{mg} / \mathrm{L})$ for the continuous feeding (Table 4). During the pulse feeding VFmulch (95\%) was also statistically better than VFgravel (70\%) and the resulting average BOD concentration in VFmulch (3 $\mathrm{mg} / \mathrm{L}$ ) was significantly lower than that of VFgravel (14 mg/L) (Table 4). In the case of the continuous feeding of VFmulch (average LR: $101 \mathrm{~g} / \mathrm{m}^{2}$. day) and considering that 1 person equivalent (PE) corresponds to $60 \mathrm{~g} \mathrm{BOD} /$ day, the surface area used was $0.6 \mathrm{~m}^{2} / \mathrm{PE}$. 


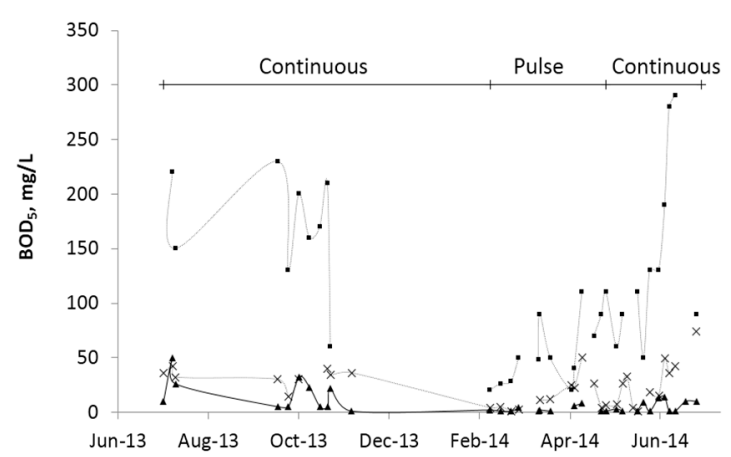

(a)

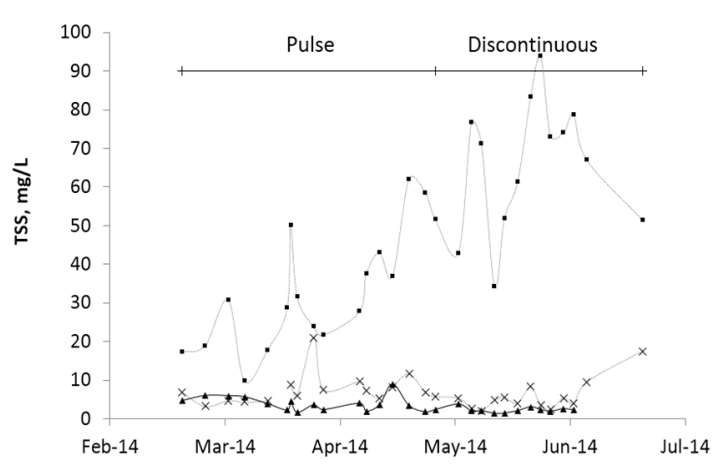

(c)

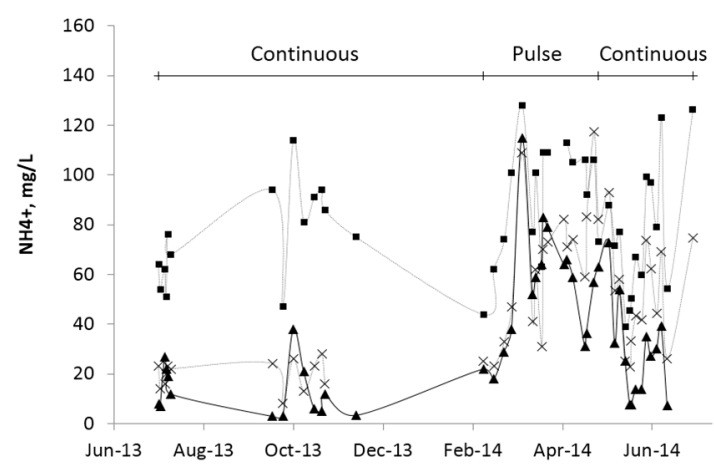

(e)

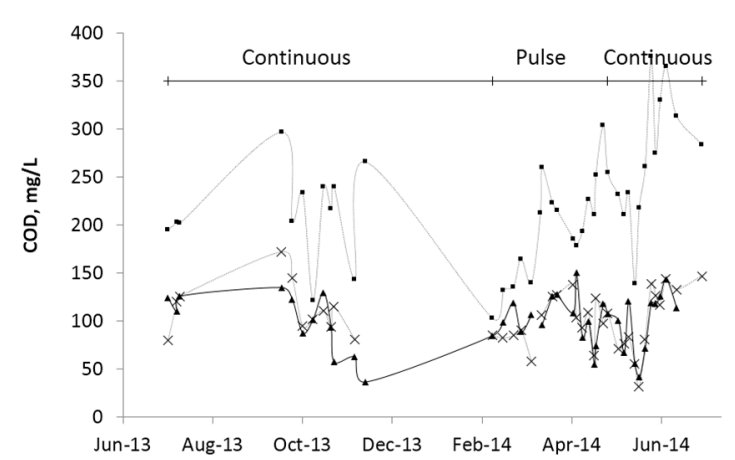

(b)

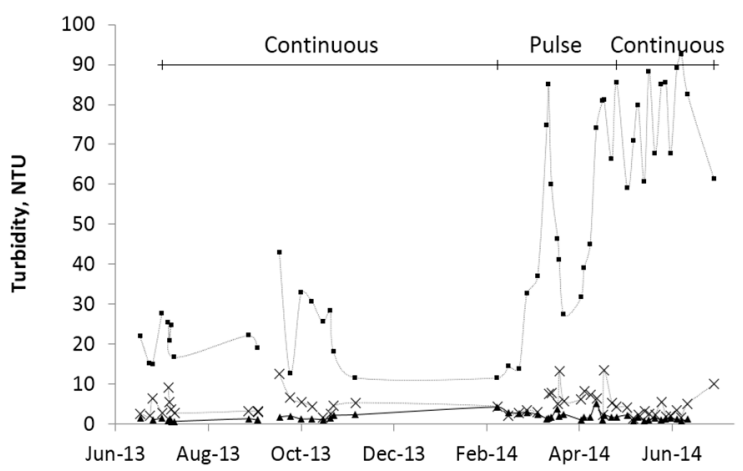

(d)

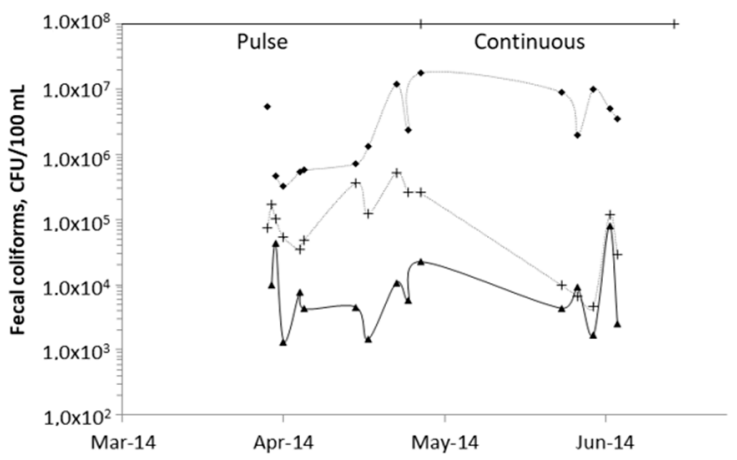

(f)

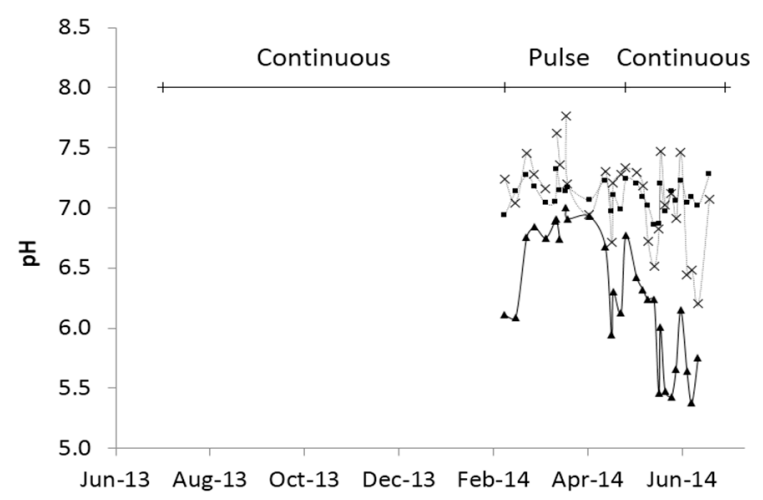

(g)

Figure 3. Values in the influent of the secondary constructed wetlands (-ם-, dashed line) and effluents of VFmulch2 (-^-', solid line) and VFgravel2 (-x-, dashed line) of: (a) BOD; (b) COD; (c) TSS; (d) turbidity; (e) $\mathrm{NH}_{4}{ }^{+}$; (f) fecal coliforms; (g) $\mathrm{pH}$. 
Table 4. Average LR, concentrations in the effluent ( \pm standard deviation) and removals (in italics) for VFgravel2 and VFmulch2 in the continuous and pulse feeding periods.

\begin{tabular}{|c|c|c|c|c|}
\hline \multirow{2}{*}{$\begin{array}{l}\text { LR* } \\
\text { Effl. conc. } \\
\text { Removal }\end{array}$} & \multicolumn{2}{|c|}{ VFgravel2 } & \multicolumn{2}{|c|}{ VFmulch2 } \\
\hline & Continuous & Pulse & Continuous & Pulse \\
\hline \multirow{3}{*}{ BOD } & $76( \pm 48)$ & $22( \pm 26)$ & $101( \pm 59)$ & $17( \pm 16)$ \\
\hline & $30( \pm 17)$ & $14( \pm 14)$ & $11( \pm 13)$ & $3( \pm 2)$ \\
\hline & 78 & 70 & 91 & 95 \\
\hline \multirow{3}{*}{ COD } & $118( \pm 44)$ & $81( \pm 63)$ & $137( \pm 63)$ & $66( \pm 39)$ \\
\hline & $106( \pm 34)$ & $100( \pm 23)$ & $99( \pm 32)$ & $103( \pm 23)$ \\
\hline & 54 & 47 & 57 & 44 \\
\hline \multirow{3}{*}{ TSS } & $25( \pm 15)$ & $15( \pm 15)$ & $32( \pm 20)$ & $11( \pm 10)$ \\
\hline & $6( \pm 4)$ & $8( \pm 4)$ & $2( \pm 1)$ & $4( \pm 2)$ \\
\hline & 84 & 73 & 93 & 84 \\
\hline \multirow{3}{*}{ Turbidity } & $26( \pm 16)$ & $21( \pm 21)$ & $32( \pm 21)$ & $17( \pm 14)$ \\
\hline & $4.1( \pm 2.6)$ & $6( \pm 3)$ & $1.3( \pm 0.5)$ & $2( \pm 1)$ \\
\hline & 85 & 85 & 95 & 92 \\
\hline \multirow{3}{*}{$\mathrm{NH}_{4}^{+}$} & $39( \pm 16)$ & $38( \pm 24)$ & $43( \pm 21)$ & $30( \pm 13)$ \\
\hline & $36( \pm 22)$ & $64( \pm 28)$ & $20( \pm 17)$ & $55( \pm 25)$ \\
\hline & 53 & 33 & 73 & 41 \\
\hline \multirow{3}{*}{$\mathrm{PO}_{4}{ }^{3-} \mathrm{P}$} & $6.2( \pm 1.96)$ & $5.5( \pm 4.2)$ & $7.2( \pm 2.9)$ & $4.2( \pm 2.6)$ \\
\hline & $10( \pm 3.9)$ & $10( \pm 2.9)$ & $11.7( \pm 5.5)$ & $10.4( \pm 3.6)$ \\
\hline & 15 & 20 & -3 & 16 \\
\hline \multirow{3}{*}{ FC } & $5.3( \pm 8) \times 10^{10}$ & $2.4( \pm 5) \times 10^{10}$ & $10( \pm 17) \times 10^{10}$ & $1.8( \pm 3) \times 10^{10}$ \\
\hline & $8.4( \pm 13) \times 10^{4}$ & $1.8( \pm 1) \times 10^{5}$ & $9.7( \pm 16) \times 10^{4}$ & $1.1( \pm 1.3) \times 10^{4}$ \\
\hline & 98 & 92.6 & 98 & 98.6 \\
\hline
\end{tabular}

Notes: ${ }^{*}$ Units for removals, concentrations and LR are $\%, \mathrm{mg} / \mathrm{L}$ and $\mathrm{g} / \mathrm{m}^{2} \cdot$ day, with the exception of turbidity (NTU and NTUxL $/ \mathrm{m}^{2}$.day) and fecal coliforms $\left(\mathrm{CFU} / 100 \mathrm{~mL}\right.$ and $\mathrm{CFU} / \mathrm{m}^{2}$. day), respectively.

The average COD LR of the VFgravel during the continuous $\left(118 \mathrm{~g} / \mathrm{m}^{2} \cdot\right.$ day $)$ and pulse $\left(81 \mathrm{~g} / \mathrm{m}^{2}\right.$.day) feeding modes were significantly different. The same results were obtained in the VFmulch. However, though the COD removals in the continuous mode seem to be greater (VFgravel: $54 \%$, VFmulch: 57\%) than those of the pulse feeding mode (VFgravel: 47\%, VFmulch: $44 \%$, Table 4 ), the difference was not significant. Consequently, the COD concentrations in the effluent of both VFs and feeding modes were similar. Thus, it can be concluded that the substrate (gravel vs. mulch) and the feeding mode (pulse vs. continuous) did not have any remarkable effect on COD removal. Nonetheless, most of the COD concentrations of the effluent of both VFs met the European legal limit of $125 \mathrm{mg} / \mathrm{L}$ (Figure 3).

Although the LR of TSS of VFgravel $\left(25 \mathrm{~g} / \mathrm{m}^{2}\right.$.day, Table 4) during the continuous feeding was significantly greater than that of the pulse mode $\left(15 \mathrm{~g} / \mathrm{m}^{2}\right.$.day), the removal of TSS $(84 \%)$ was better $(p=0.0002)$ than that of the pulse one $(73 \%)$. The same results were achieved with VFmulch, which obtained a significantly better $(p=0.0001)$ removal with continuous feeding $(93 \%)$ than with the pulse one $(84 \%)$ in spite of the fact that the average LR of TSS in continuous $\left(32 \mathrm{~g} / \mathrm{m}^{2}\right.$.day) was significantly greater than that of the pulse period $\left(11 \mathrm{~g} / \mathrm{m}^{2}\right.$.day). Consequently, the average TSS concentration in the effluent of VFmulch when fed in continuous $(2 \mathrm{mg} / \mathrm{L})$ was statistically lower than that of the pulse mode $(4 \mathrm{mg} / \mathrm{L})$. In the case of VFgravel, the concentration of TSS in the effluent was lower in the continuous mode $(6 \mathrm{mg} / \mathrm{L})$ but not significantly. In conclusion, the best TSS removals were achieved by VFmulch with the continuous feeding mode.

A similar result was obtained for turbidity. The LR of turbidity of VFgravel and VFmulch in both feeding modes were statistically similar. VFmulch improved significantly its performance $(p=0.00036)$ when fed in continuous (95\%) compared with the pulse mode $(92 \%)$. This was not the case for VFgravel as removals were the same in both feeding modes ( $85 \%)$. Besides, turbidity removal was significantly better with mulch independently of the feeding mode $(p=0.007)$. The average effluent turbidity values 
of the VFmulch were improved $\left(p=8.9 \times 10^{-5}\right)$ with the continuous regime $(1.3 \mathrm{NTU})$ in comparison with the pulse one (2 NTU).

The average LR of ammonia of VFgravel and VFmulch were statistically similar in both feeding modes (Table 4). VFgravel improved ammonia removal significantly when fed continuously (53\%) in comparison to that of the pulse feeding (33\%). VFmulch also improved significantly with the continuous feeding $(73 \%)$ compared with that of pulse one $\left(41 \%, p=2.3 \times 10^{-5}\right)$. Additionally, VFmulch was more efficient than VFgravel with both the continuous and pulse feeding modes. Between February and July 2014, the average pH of the influent of the VFs was $7.10( \pm 0.12)$ and those of VFgravel and VFmulch were $7.09( \pm 0.37)$ and $6.27( \pm 0.37)$, respectively. The stronger acidification of the VFmulch effluent (Figure 3) is in agreement with its higher ammonia removal. Additionally, during the continuous feeding of both reactors their effluent $\mathrm{pH}$ were lower (VFgravel: 6.91, VFmulch: 5.86) than those of the pulse feeding period (VFgravel: 7.26, VFmulch: 6.61). These results suggest that the main ammonia removal mechanism was nitrification [35]. The efficiencies regarding COD and $\mathrm{NH}_{4}{ }^{+}$removals of VFmulch with the continuous feeding (Table 4) are comparable to those achieved by Zhao et al. [18] in the treatment of anaerobic digested swine wastewater with a wood-chip-framework soil infiltrator. These authors used LR of COD and $\mathrm{NH}_{4}{ }^{+} \mathrm{LR}$ of $26-118 \mathrm{~g} / \mathrm{m}^{2} \cdot$ day and $22-106 \mathrm{~g} / \mathrm{m}^{2} \cdot$ day and achieved removals of $67.5-48 \%$ and $82-78 \%$, respectively.

Physical, chemical and biological factors are responsible for the removal of fecal bacteria and pathogens in CWs. Physical factors include mechanical filtration, sedimentation, and sorption to organic matter and the CW's substrate. Chemical factors comprise oxidation and exposure to biocides excreted by plants. Biological factors involve antimicrobial activity of root exudates, predation, retention in biofilms, natural die-off, etc. [36]. The LR of FC of VFgravel in the continuous mode $\left(5.3 \times 10^{10} \mathrm{CFU} / \mathrm{m}^{2}\right.$. day, Table 4$)$ was significantly greater than that of the pulse one $\left(2.4 \times 10^{10} \mathrm{CFU} / \mathrm{m}^{2}\right.$.day). The same result was obtained with VFmulch. Yet, the removals of VFmulch in continuous and pulse feeding, and VFgravel in continuous $(98.2 \%, 98.6 \%$ and $98 \%$, respectively) were similar and superior to that of conventional VFgravel in the pulse feeding period (92.6\%). Note that the lowest removal of FC coincided with those of TSS and ammonia (Table 4). This result suggests that both the mulch and the continuous feeding improved the effect of media filtration [37] and aeration [38]. Saeed and Sun [35] also observed improved removal of FC in wood mulch in comparison with gravel in bench-scale VFs. The authors attributed it to the effect of aerobic conditions on the promotion of the growth of heterotrophic protozoa and E. coli cell oxidation.

Regarding phosphate-P removal the differences shown by the VFs (Table 4) are not relevant. No significant differences were found between influent and effluent concentrations for both reactors fed in continuous nor in pulse. Removals were not significantly different with either the continuous or the pulse feedings. Thus, it can be concluded that the capacity of these reactors to remove dissolved phosphate-P was nil. Similarly to other forest and agricultural waste/by-products, the low efficiency of the palm mulch in the removal of the negatively charged phosphate ions can be attributed to the abundant availability of negatively charged functional groups (e.g., $-\mathrm{OH},-\mathrm{COOH}$ ) and the absence of positively charged functional groups (e.g., $-\mathrm{NH}_{2}$ ) on its surface [20]. Nevertheless, far from being a disadvantage the modest efficiency of CWs in the removal of $\mathrm{N}$ and $\mathrm{P}$ can be regarded as a way to decrease the demand for expensive inorganic fertilizers in agriculture [39]. For instance, García-Delgado et al. [40] saved considerable amounts of fertilizer ( $37 \% \mathrm{~N}, 66 \% \mathrm{P}$ and $12 \% \mathrm{~K}$ ) by applying treated urban wastewater in pepper cultivation. In fact, wastewater effluent reuse has been widely implemented in many countries with Israel and California (USA) leading wastewater reuse with $65-70 \%$ of the wastewater reused in agriculture [41].

These results show that palm mulch is a better substrate than gravel for VFs and that the continuous feeding mode can improve performance of VFs, particularly that of conventional (gravel-based, pulse fed) ones. Note that the goal of the pulse feeding of VFs is to improve the substrate aeration and the reactor efficiency. Nevertheless, the obtained results show that a continuous feeding can yield better results. Thus, it seems that the continuous feeding provided enough oxygen 
to the substrate. In fact, the pulse feeding requires adding larger volumes of water in shorter time periods to achieve the same HLR. This probably results in shorter HRTs and consequently worse performance. The combination of HF1 with VFmulch in the continuous feeding period provided remarkable removals of COD $(82 \%)$, BOD $(97 \%)$, TSS and turbidity $(99 \%)$, ammonia $(65 \%)$ and FC $(99.8 \%)$ and nil of phosphate $(-4 \%)$.

The better efficiency of the mulch with respect to gravel can be explained by considering the particular characteristics of the former. In this regard, one the most important features of the mulch is its small particle size and compressibility. A smaller particle size provides longer HRT and improved water distribution on the reactor surface, better retention of particles (TSS), micelles (turbidity) and bacteria, including the heterotrophic bacteria responsible for the degradation of dissolved BOD, nitrifying bacteria and fecal coliforms. In addition to this, Paing et al. indicated that the presence of a sludge layer on the surface of French VFs improved performance [11]. In the present case, the accumulation of sludge on the surface of VFmulch was more evident than in VFgravel. Saeed and Sun [35] found that eucalyptus wood mulch was a better substrate than gravel for VFs as improved removals of total nitrogen, organic matter and E. coli were obtained. The authors concluded that the higher void volume percentage of the organic substrate provided higher oxygen transfer efficiency. Another interesting feature of the mulch is its hygroscopicity which was determined to be about $10 \%$ in weight. A highly hygroscopic substrate would improve plant root growth, biofilm establishment and stability, providing longer HRT and consequently better treatment performance [42]. Moreover, the smaller particle size and hygroscopicity of the mulch can help to better distribute the influent inside the reactor, thus reducing the negative effects of shortcuts and preferential paths.

\section{Conclusions}

The first stage of a hybrid CW, a mulch-based HF, has shown a remarkable performance with no symptoms of clogging for 3 years.

Experiments with the hybrid CW second stage, the bench-scale VFs have shown that:

- palm mulch is a better substrate than gravel for VFs,

- $\quad$ with two vertical VFs in series the European legal limits regarding COD, BOD and TSS can be met even when high LR are applied,

- $\quad$ the continuous influent feeding mode significantly improved performance.

The high efficiency of the reactors studied makes them particularly adequate for places where palm mulch is available, evapotranspiration is high and the reclaimed water is intended to be reused for irrigation.

Acknowledgments: This work was partially funded by the Department of Chemistry of the University of Las Palmas de Gran Canaria. The English was revised by Colm Sullivan.

Author Contributions: The idea of this article was developed by José Alberto Herrera-Melián and Alejandro Borreguero-Fabelo. Sampling and analyses were performed by Alejandro Borreguero-Fabelo and Néstor Peñate-Castellano. The paper was written by José Alberto Herrera-Melián, Javier Araña and José Alejandro Ortega-Méndez.

Conflicts of Interest: The authors declare no conflict of interest.

\section{References}

1. García-Herrera, R.; Gallego, D.; Hernández, E.; Gimeno, L.; Ribera, P.; Calvo, N. Precipitation trends in the Canary Islands. Int. J. Climatol. 2003, 23, 235-241. [CrossRef]

2. Martín, I.; Betancort, J.R.; Pidre, J.R. Contribution of non-conventional technologies for sewage treatment to improve the quality of bathing waters (ICREW project). Desalination 2007, 215, 82-89. [CrossRef]

3. Rousseau, D.P.L.; Vanrolleghem, P.A.; De Pauw, N. Constructed wetlands in Flanders: A performance analysis. Ecol. Eng. 2004, 23, 151-163. [CrossRef] 
4. Mander, Ü.; Dotro, G.; Ebie, Y.; Towprayoone, S.; Chiemchaisri, C.; Nogueira, S.; Jamsranjav, B.; Kasaka, K.; Truua, J.; Tournebize, J.; et al. Greenhouse gas emission in constructed wetlands for wastewater treatment: A review. Ecol. Eng. 2014, 66, 19-35. [CrossRef]

5. Dixon, A.; Simon, M.; Burkitt, T. Assessing the environmental impact of two options for small-scale wastewater treatment: Comparing a reedbed and an aerated biological filter using a life cycle approach. Ecol. Eng. 2003, 20, 297-308. [CrossRef]

6. Knowles, P.; Dotro, G.; Nivala, J.; García, J. Clogging in subsurface-flow treatment wetlands: Occurrence and contributing factors. Ecol. Eng. 2011, 37, 99-112. [CrossRef]

7. Zurita, F.; De Anda, J.; Belmont, M.A. Treatment of domestic wastewater and production of commercial flowers in vertical and horizontal subsurface-flow constructed wetlands. Ecol. Eng. 2009, 35, 861-869. [CrossRef]

8. Masi, F.; Martinuzzi, N. Constructed wetlands for the Mediterranean countries: Hybrid systems for water reuse and sustainable sanitation. Desalination 2007, 215, 44-55. [CrossRef]

9. Herrera-Melián, J.A.; Martín Rodríguez, A.J.; Araña, J.; González Díaz, O.; González Henríquez, J.J. Hybrid constructed wetlands for wastewater treatment and reuse in the Canary Islands. Ecol. Eng. 2010, 36, 891-899. [CrossRef]

10. Peñate, B.; Martel, G.; Vera, L.; Márquez, M.; Gutiérrez, J.; Moreno, E.; del Castillo, G.; Farrujia, I. El Agua en Canarias. Ed. Canarian Technological Institute, Department of Water. 2013. Available online: http:/ / islhagua.org/c/document_library /get_file?p_1_id=23769\&folderId=23758\&name= DLFE-1002.pdf (accessed on 3 January 2018).

11. Paing, J.; Guilbert, A.; Gagnon, V.; Chazarenc, F. Effect of climate, wastewater composition, loading rates, system age and design on performances of French vertical flow constructed wetlands: A survey based on 169 full scale systems. Ecol. Eng. 2015, 80, 46-52. [CrossRef]

12. Fuchs, V.J.; Mihelcic, J.R.; Gierke, J.S. Life cycle assessment of vertical and horizontal flow constructed wetlands for wastewater treatment considering nitrogen and carbon greenhouse gas emissions. Water Res. 2011, 45, 2073-2081. [CrossRef] [PubMed]

13. Song, X.; Ding, Y.; Wang, Y.; Wang, W.; Wang, G.; Zhou, B. Comparative study of nitrogen removal and bio-film clogging for three filter media packing strategies in vertical flow constructed wetlands. Ecol. Eng. 2015, 74, 1-7. [CrossRef]

14. Vymazal, J. Removal of nutrients in various types of constructed wetlands. Sci. Total Environ. 2007, 380, 48-65. [CrossRef] [PubMed]

15. Tee, H.C.; Seng, C.E.; Noor, A.M.; Lim, P.E. Performance comparison of constructed wetlands with graveland rice husk-based media for phenol and nitrogen removal. Sci. Total Environ. 2009, 407, 3563-3571. [CrossRef] [PubMed]

16. Wang, R.Y.; Korboulewsky, N.; Prudent, P.; Domeizel, M.; Rolando, C.; Bonin, G. Feasibility of using an organic substrate in a wetland system treating sewage sludge: Impact of plant species. Bioresour. Technol. 2010, 101, 51-57. [CrossRef] [PubMed]

17. Gibert, O.; de Pablo, J.; Cortina, J.L.; Ayora, C. Chemical characterization of natural organic substrates for biological mitigation of acid mine drainage. Water Res. 2004, 38, 4186-4196. [CrossRef] [PubMed]

18. Zhao, B.; Li, J.; Leu, S. An innovative wood-chip-framework soil infiltrator for treating anaerobic digested swine wastewater and analysis of the microbial community. Bioresour. Technol. 2014, 173, 384-391. [CrossRef] [PubMed]

19. Bhatnagar, A.; Sillanpaa, M. Utilization of agro-industrial and municipal waste materials as potential adsorbents for water treatment-A review. Chem. Eng. J. 2010, 157, 277-296. [CrossRef]

20. Nguyen, T.A.H.; Ngo, H.H.; Guo, W.S.; Zhang, J.; Liang, S.; Lee, D.J.; Nguyen, P.D.; Bui, X.T. Modification of agricultural waste/by-products for enhanced phosphate removal and recovery: Potential and obstacles. Bioresour. Technol. 2014, 169, 750-762. [CrossRef] [PubMed]

21. Ribé, V.; Nehrenheim, E.; Odlare, M.; Gustavsson, L.; Berglind, R.; Forsberg, Å. Ecotoxicological assessment and evaluation of a pine bark biosorbent treatment of five landfill leachates. Waste Manag. 2012, 32, 1886-1894. [CrossRef] [PubMed]

22. Gao, R.Y.; Shao, L.; Li, J.S.; Guo, S.; Han, M.Y.; Meng, J.; Liu, J.B.; Xu, F.X.; Lin, C. Comparison of greenhouse gas emission accounting for a constructed wetland wastewater treatment system. Ecol. Inform. 2012, 12, 85-92. [CrossRef] 
23. Sajdak, L.M.; Velazquez-Martí, B.; Lopez-Cortés, I. Quantitative and qualitative characteristics of biomass derived from pruning Phoenix canariensis hort. ex Chabaud. and Phoenix dactilifera L. Renew. Energy 2014, 71, 545-552. [CrossRef]

24. Directive, EU Urban Wastewater. Council directive 91/271/EEC of 21 May 1991, concerning urban waste water treatment (91/271/EEC). Off. J. Eur. Communities 1991, 40-52. Available online: http:/ / eur-lex.europa. eu/legal-content/EN/TXT/?uri=CELEX:31991L0271 (accessed on 3 January 2018).

25. Herrera-Melián, J.A.; González-Bordón, A.; Martín-González, M.A.; García-Jiménez, P.; Carrasco, M.; Araña, J. Palm tree mulch as substrate for primary treatment wetlands processing high strength urban wastewater. J. Environ. Manag. 2014, 139, 22-31. [CrossRef] [PubMed]

26. Santana Rodríguez, J.J.; Santana Hernández, F.J.; González González, J.E. The effect of environmental and meteorological variables on atmospheric corrosion of carbon steel, copper, zinc and aluminium in a limited geographic zone with different types of environment. Corros. Sci. 2003, 45, 799-815. [CrossRef]

27. American Public Health Association (APHA). Standard Methods for the Examination of Water and Wastewater, 21st ed.; American Public Health Association: Washington, DC, USA, 2005.

28. Albuquerque, A.; Arendacz, M.; Gajewska, M.; ObarskaPempkowiak, H.; Randerson, P.; Kowalik, P. Removal of organic matter and nitrogen in a horizontal subsurface flow (HSSF) constructed wetland under transient loads. Water Sci. Technol. 2009, 60, 1677-1682. [CrossRef] [PubMed]

29. Konnerup, D.; Koottatep, T.; Brix, H. Treatment of domestic wastewater in tropical, subsurface flow constructed wetlands planted with Canna and Heliconia. Ecol. Eng. 2009, 35, 248-257. [CrossRef]

30. Fan, J.; Wang, W.; Zhang, B.; Guo, Y.; Ngo, H.H.; Guo, W.; Zhang, J.; Wu, H. Nitrogen removal in intermittently aerated vertical flow constructed wetlands: Impact of influent COD/N ratios. Bioresour. Technol. 2013, 143, 461-466. [CrossRef] [PubMed]

31. Zhi, W.; Yuan, L.; Ji, G.; He, C. Enhanced long-term nitrogen removal and its quantitative molecular mechanism in tidal flow constructed wetlands. Environ. Sci. Technol. 2015, 49, 4575-4583. [CrossRef] [PubMed]

32. Kadlec, R.H.; Knight, R.L. Treatment Wetlands; CRC Press: Boca Raton, FL, USA, 1996; p. 893.

33. Sengupta, M.E.; Keraita, B.; Olsen, A.; Boateng, O.K.; Thamsborg, S.T.; Pálsdóttir, G.R.; Dalsgaard, A. Use of Moringa oleifera seed extracts to reduce helminth egg numbers and turbidity in irrigation water. Water Res. 2012, 46, 3646-3656. [CrossRef] [PubMed]

34. Zurita, F.; White, J.R. Comparative Study of Three Two-Stage Hybrid Ecological Wastewater Treatment Systems for Producing Reclaimed Water for Agricultural Reuse. Water 2014, 6, 213-228. [CrossRef]

35. Saeed, T.; Sun, G. Enhanced denitrification and organics removal in hybrid wetland columns: Comparative experiments. Bioresour. Technol. 2011, 102, 967-974. [CrossRef] [PubMed]

36. Wu, S.; Carvalho, P.N.; Müller, J.A.; Manoj, V.R.; Dong, R. Sanitation in constructed wetlands: A review on the removal of human pathogens and fecal indicators. Sci. Total Environ. 2016, 541, 8-22. [CrossRef] [PubMed]

37. Karim, M.R.; Manshadi, F.D.; Karpiscak, M.M.; Gerba, C.P. The persistance and removal of enteric pathogens in constructed wetlands. Water Res. 2004, 38, 1831-1837. [CrossRef] [PubMed]

38. Headley, T.; Nivala, J.; Kassa, K.; Olsson, L.; Wallace, S.; Brix, H.; van Afferden, M.; Müller, R. Escherichia coli removal and internal dynamics in subsurface flow ecotechnologies: Effects of design and plants. Ecol. Eng. 2013, 61, 564-574. [CrossRef]

39. Almuktar, A.; Scholz, M.; Al-Isawi, R.; Sani, A. Recycling of domestic wastewater treated by vertical-flow wetlands for irrigating Chillies and Sweet Peppers. Agric. Water Manag. 2015, 149, 1-22. [CrossRef]

40. García-Delgado, C.; Eymar, E.; Contreras, J.I.; Segura, M.L. Effects of fertigation with purified urban wastewater on soil and pepper plant (Capsicum annuиm L.) production, fruit quality and pollutant contents. Span. J. Agric. Res. 2012, 10, 209-221. [CrossRef]

41. Kihila, J.; Mtei, K.M.; Njau, K.N. Wastewater treatment for reuse in urban agriculture; the case of Moshi Municipality, Tanzania. Phys. Chem. Earth 2014, 72-75, 104-110. [CrossRef]

42. Bruch, I.; Fritsche, J.; Bänninger, D.; Alewell, U.; Sendelov, M.; Hürlimann, H.; Hasselbach, R.; Alewell, C. Improving the treatment efficiency of constructed wetlands with zeolite-containing filter sands. Bioresour. Technol. 2011, 102, 937-941. [CrossRef] [PubMed] 
(C) 2018 by the authors. Licensee MDPI, Basel, Switzerland. This article is an open access article distributed under the terms and conditions of the Creative Commons Attribution (CC BY) license (http:// creativecommons.org/licenses/by/4.0/). 